\title{
Indonesia Democracy Index (IDI) Forecasting in 2019 using Moving Average and Correlation Between IDI's Aspect Using Pearson Correlation Coefficient
}

\author{
$1^{\text {st }}$ Faisal Rahutomo \\ Information Technology Department \\ State Polytechnic of Malang \\ Malang, Indonesia \\ faisal@polinema.ac.id \\ $4^{\text {th }}$ Ngatmari \\ Department of Electronic Engineering \\ State Polytechnic of Malang \\ Malang, Indonesia \\ marymalangcity@gmail.com
}

\author{
$2^{\text {nd }}$ Dimas Rossiawan Hendra Putra \\ Department of Electronic Engineering \\ State Polytechnic of Malang \\ Malang, Indonesia \\ dimas.rossi@polinema.ac.id
}

\author{
$3^{\text {rd }} \mathrm{M}$ bisri Musthofa \\ Department of Electronic Engineering \\ State Polytechnic of Malang \\ Malang, Indonesia \\ ichsancomp@gmail.com
}

\begin{abstract}
This experiment aims to analyze the forecasting of the Indonesian Democracy Index (IDI) in 2019, which uses each province data by the Moving Average method. The parame te us used in this experiment refer to data obtained from the Central Statistics Agency (BPS) in 2009-2018. The le vel of achie vement of IDI is measured based on the de velopment and implementation of 3 aspects, 11 variables, and 28 indicators. Experiment purposes to find the average percentage of absolute error MAPE (Mean Absolute Percentage Frror) for each province and looks for correlations between the three main aspects of forming IDI namely civil liberties, political rights, and democratic institutions. IDI Indonesia's forecasting results in 2019 the IDI has an average value of 68.28 with a MAPE of $4.78 \%$. The results of the correlation between the three aspects of forming the IDI using the Pearson correlation coefficient resulted in the aspect of civil liberties having no correlation with aspects of political rights or aspects of democratic institutions with Pearson values of $\mathbf{- 0 . 0 5}$ and $-\mathbf{0 . 1 9}$. Whereas aspects of political rights correlate with democratic institutions with Pearson's value of 0.48 .
\end{abstract}

Keywords-Forecasting, Indonesian Democracy Index, Moving Average. Pearson Correlation Coefficient.

\section{INTRODUCTION}

The Indonesian Democracy Index (IDI) is a composite indicator and shows the rate of development of democracy in Indonesia. The level of achievement is calculated based on the development and implementation of 3 main aspects, namely the aspect of civil liberties, political rights, and democratic institutions. IDI figures show that from 2009 to 2018, the level of democracy in Indonesia experienced dynamic turmoil. Period 2009 - 2013, IDI numbers have a range of 60s, while the 2014-2018 period IDI numbers are in the range of $70 \mathrm{~s}$. The level of democracy is classified into three labels, namely "good" with an index > 80, "moderate" with an index of 60-80, and "bad" with an index $<60$. This shows that the national IDI level is still in the "moderate" category, despite having experienced an increase compared to the level of democracy five years ago. National IDI's figure for the year 2009-2018 is shown in Figure 1. The dynamics of IDI are formed from the three aspects that form IDI, namely the Aspect of Civil Liberties, the Aspects of Political Rights, and the Aspects of Democratic Institutions.
These three aspects show trends that vary from 2009 to 2018. The aspect of Civil liberties displays changes or fluctuations with a trend that is "softer" compared to the other two aspects. The aspect of Civil Liberties was in the "good" category in the range of $2009-2011$ and in $2014-2015$, with the lowest achievement in 2016 of 76.45 points. The political rights aspect is in the "bad" category in the range 2009-2013 and has increased in the 2013-2015 range from 46.25 to 70.63 points. After 2015 the Political Rights aspect displayed a declining trend despite still included in the category of "medium". Aspects of Democratic Institutions in the 2009-2018 period are always included in the "medium" category with the highest achievements in 2014 of 75.81 and the lowest achievements in 2016 of 62.05 . The development of the main as pects of determining IDI is shown in Figure 2.

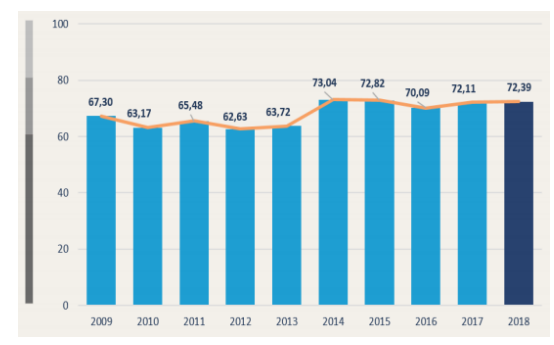

Fig. 1. National IDI's Value in 2009-2018

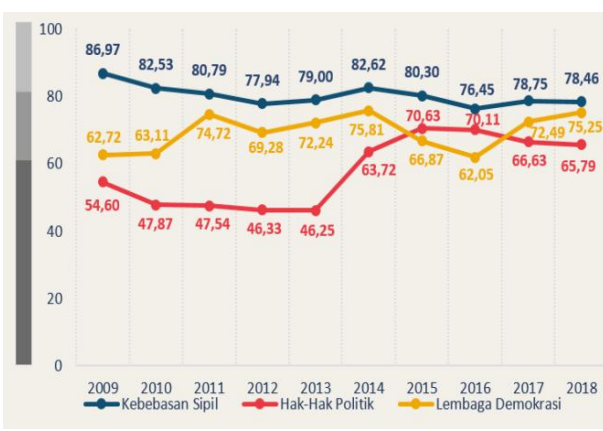

Fig. 2. IDI's Aspect Index in 2009-2018 
The challenges in analyze IDI's data based on provinces are providing policies and recommendations, which so far have not helped many parties concerned with analyze and improve provincial IDI values, so one of the functions of forecasting is needed. By finding the average absolute error of MAPE (Mean Absolute Percentage Error) for each province in Indonesia and to get the IDI's value in 2019, the data can provide the estimation of prediction, so the local govemment can use the data to increase the IDI's value in their provinces by increasing the sub-parameter value in hope that the IDI number for the following years will be better.

This experiment using forecasting in knowing MAPE for every province in Indonesia using data from the Central Statistics Agency (BPS) in 2009-2018. From these data, there are sub-parameter data on IDI's aspect, the subparameter on aspects of civil liberties are freedom of association and association, freedom of opinion, freedom of belief, and freedom from dis crimination. The sub-parameters on political rights are the right to vote and be elected and political participation in making decisions and monitoring the govemment. The sub-parameter on democratic institutions consisting of free and fair elections, the role of the DPRD (Regional People's Representative Assembly), the role of political parties, the role of local govemment bureaucracy, and an independent judiciary. The results of this experiment explain that forecasting using the moving method produces all provinces fall into the "medium" classification results, but there are two provinces who get results near "good", which is DI Yogyakarta and DKI Jakarta. This experiment is also to look for correlations between the three aspects that form IDI which aim to measure a linear relationship between three main parameters: Civil Liberties, Political Rights, and Democratic Institutions. Correlation analysis does not show a functional relationship. But to find out whether or not there is a relationship between these three variables. The correlation just measures the closeness of three main aspects of IDI.

\section{LITERATURE REVIEW}

\section{A. Moving Average}

Moving average is one of the forecasting methods that are useful for smoothing past data for technical forecasting, called "moving" because as new data available the oldest data is not used anymore [1]. The main purpose of moving averages is to reduce randomness in time series. This method moves in a time series cons is ting of taking a set of observed values, then getting an average of this set. The average value is used as a forecast that will come. The average value is calculated based on the amount of power, the moving average number is determined from the first value to the $\mathrm{N}$ value of the data held. Moving averages are calculated using the formula in Equation 1 below:

$$
F_{t+1}=\frac{1}{N} \sum_{i=t-N+1}^{t} X_{i}
$$

Information:

$$
\begin{aligned}
& t=\text { The most recent value } \\
& t+1=\text { The next period in which a prediction is made } \\
& \mathrm{Ft}+1=\text { Forecasts for the period } \mathrm{t}+1
\end{aligned}
$$

\section{$\mathrm{Ct}, \mathrm{t}-1, \mathrm{t}-2=$ Observation values in periods $\mathrm{t}, \mathrm{t}-1, \mathrm{t}-2$}

$\mathrm{N}=$ Number of observations used in calculating moving averages.

Moving averages have the disadvantage that all observational data have the same weight in forming their averages. The latest observation data should have a greater weight than the past observation data. The double moving average method used to reduce systematic errors that occur, according to the symbol is written as MA (M X N) where $\mathrm{M}$ is the period of MA N-Period. The moving average forecasting procedure includes three aspects: Use moving average against time t. Adjusting the difference between the single moving average and the double moving average. Adjustments for trends fromperiod $\mathrm{t}$ to period $\mathrm{t}+\mathrm{m}$.

The second adjustment is considered most effective if the trend is linear and the random error is not that large. This correction is effective because the single MA lags behind the data series that show trends. When the data series shows a trend, then a single MA will display graphs such as systematic errors and systematic errors can be reduced by using the difference between the value of the single moving average and double moving average [3]. The general linear moving procedure is generally displayed by the following equation:

$$
\begin{aligned}
& S_{t}^{r}=\frac{X_{L}+X_{L-1}+X_{L-2}+\cdots+X_{L}-N+1}{N} \\
& S^{n}{ }_{t}=\frac{S_{t}+S_{t-1}^{r}+S_{t-2}^{r}+\cdots+S_{t-N+1}^{r}}{N} \\
& a_{t}=s_{t}^{t}+\left(s_{t}^{t}-s^{t n}\right)=2 S_{t}^{t}-s^{n t}{ }_{t} \\
& b_{t}=\frac{2}{N-1}\left(S_{t}^{s}-S_{t}^{s s}\right) \\
& F_{t-m}=a_{t}+b_{t} m
\end{aligned}
$$

\section{B. Trend Analysis method}

Trend Analys is is a method that separates three basic components namely trend, cycle, and seasonal factors. Matching a straight line to stationary data (horizontal) can be done by minimizing Mean Square Error (MSE) using Equation 7 and linear trend lines for periodic series data using Equation 8:

$$
\begin{aligned}
& \vec{X}=\frac{\sum_{i=1}^{n} X_{i}}{n} \\
& X_{t}=a+b_{t}
\end{aligned}
$$

Values $a$ and $b$ that minimize MSE are obtained using Equations 9 and 10 where $\mathrm{a}$ is an intercept and $\mathrm{b}$ is a slope:

$$
\begin{aligned}
& a=\frac{\sum X}{n}-b \frac{\sum t}{n} \\
& b=\frac{n \sum t X-\sum t \sum X}{n \sum t^{2}-\left(\sum t\right)^{2}}
\end{aligned}
$$

\section{Measure ForecastAccuracy}

Measuring the accuracy of forecasting results is the magnitude of the error value difference between forecasting results with actual or existing data, there are four commonly used measures: Mean Absolute Deviation (MAD), Mean Square Error (MSE), Mean Forecast Error (MFE), and Mean Absolute Percentage Error (MAPE). MAD is the average of 
absolute errors over a certain period regardless of forecasting results whether they are bigger or smaller than the facts. MAD is formulated like Equation 11:

$$
M A D=\sum\left|\frac{A_{\mathrm{t}}-F_{\mathrm{t}}}{n}\right|
$$

MSE is calculated by squaring all forecast errors in each period and dividing by the number of forecast periods, formulated as Equation 12:

$$
\text { MSE }=\sum \frac{\left(A_{\mathrm{t}}-F_{\mathrm{t}}\right)^{2}}{n}
$$

Mean Forecast Error (MFE) is effective to find out whether a forecast result during a certain time is too low or too high. If the forecasting results are not biased, then the MFE value will be close to zero. MFE is calculated by adding up all forecasting errors during the forecasting period, then dividing by the number of forecasting periods. The MFE is shown in Equation 13 below:

$$
M F E=\sum \frac{\left(A_{\mathrm{t}}-F_{\mathrm{t}}\right)}{n}
$$

MAPE is a relative measure of error, MAPE is more widely us ed than MAD because MAPE states the percentage error forecast results from actual data during a certain period in the form of a percentage. MAPE is systematically stated as follows:

$$
\text { MAPE }=\left(\frac{100}{n}\right) \sum\left|A_{t}-\frac{F_{t}}{A_{t}}\right|
$$

Information:

$$
\begin{aligned}
& \mathrm{At}=\text { actual data in the } \mathrm{t} \text {-period } \\
& \mathrm{Ft}=\text { Forecasting of datain the } \mathrm{t} \text {-period } \\
& \mathrm{n}=\text { Mean Square Error (MSE) }
\end{aligned}
$$

\section{Aspects of Civil Liberties, Political Rights and}

\section{Democratic Institutions}

The main aspects of forming IDI are civil liberties, political rights, and democratic institutions. Civil liberties have four variables: freedom to getting together and association, freedom of opinion, freedom of belief, and freedom from discrimination. The aspect of political rights has two variables consisting of the right to vote and be elected and political participation in decision making.

Style Aspects of democratic institutions have four variables cons isting of the role of DPRD, the role of political parties, the role of local government bureaucracy, and an independent judiciary. IDI's data collection uses quantitative and qualitative approaches. The first stage of quantitative data was collected from coding written documents and newspapers such as regulations and decisions of regional heads or local regulations following IDI indicators. The second stage is verifying and elaborating, as well as exploring cases that are not captured in the coding of documents or newspapers. The third step is to verify the data collected through in-depth interviews with competent informants who provide information about IDI indicators. All of these stages are carried out by the Provincial BPS, processed at the RI BPS, and verified by the Central IDI team for each stage. This experiment will also look for correlations between the three aspects of forming IDI using the pearson correlation coefficient.

\section{E. Pearson Correlation Coefficient}

Pearson Correlation Coefficient is a statistical formula that can help measure the relationship between two variables. Statistics often refer to this method as the Pearson R test. Coefficient values can range from -1.00 to 1.00 . If the coefficient value is in the negative range, then the relationship between the two variables is negatively correlated. Similarly, if the value in the positive range, then the relationship between the two variables is positively correlated [3]. The equation to determine the Pearson correlation coefficient is shown in Equation 15.

$$
r=\frac{N \sum x y-\left(\sum x\right)\left(\sum y\right)}{\sqrt{\left[N \sum x^{2}-\left(\sum x\right)^{2}\right]\left[N \sum y^{2}-\left(\sum y\right)^{2}\right]}}
$$

Information:

$$
\begin{aligned}
& N \quad=\text { number of pairs to be correlated. } \\
& \sum x y=\text { number of times the two pairs multiplied } \\
& \sum x=\text { number of first pair values }(\mathrm{x}) \\
& \sum y=\text { number of values of the second pair }(\mathrm{y}) \\
& \sum x^{2}=\text { sumof squared values of } \mathrm{x} \\
& \sum y^{2}=\text { sumof squared values } \mathrm{y}
\end{aligned}
$$

\section{F. Arithmetic, Geometric, andHarmonic Means}

The average is a value that represents a set of data. The role of the mean value is to reflect the value in the group. If the value has the same unit or type of value it is better to use the arithmetic mean, if it has a different unit or type of value use the geometric mean and if the value is in the form of "rate" it is better to use the harmonic mean [5]. The arithmetic, geometric, and harmonic mean equations are displayed in the following Equations:

$$
\begin{aligned}
& \text { Arithmetic mean }=\frac{x_{1}+x_{2}+\cdots+x_{n}}{n} \\
& \text { Geometric mean }=\sqrt[n]{x_{1}+x_{2}+\cdots+x_{n}} \\
& \text { Harmonic mean }=\frac{n}{\frac{1}{x_{n}}+\frac{1}{x_{n}}+\cdots+\frac{1}{x_{n}}}
\end{aligned}
$$

\section{Methodology}

Data collection is carried out in accordance with the sources and types of data needed. In this study, data collection is done by observing the data that has been provided by the Indonesian Central Statistics Agency. The data provided are in the form of Indonesian Democratic Index Statistics data from 2009 to 2018. From the results of the data obtained there are 3 aspects, 11 variables and 28 indicators in determining the Indonesian Democracy Index. North Kalimantan is a new province so it determines data for 2009-2014 using average values from 2015-2018. The flowchart of this experiment is shown in Figure 3 and the Provincial IDI Figures is shown in Table 1. 


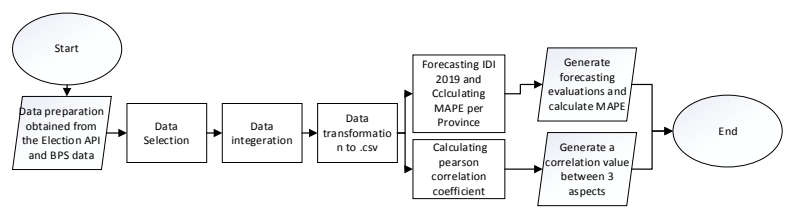

Fig. 3. Experiment Flowchart

TABLE 1. Provincial IDI VALUeS IN 2009-2018

\begin{tabular}{|c|c|c|c|c|c|c|c|c|c|c|}
\hline \multirow{2}{*}{ Provinsi } & \multicolumn{10}{|c|}{ Indeks Demokrasi Indonesia (IDI) Menurut Provinsi } \\
\hline & 2009 & 2010 & 2011 & 2012 & 2013 & 2014 & 2015 & 2016 & 2017 & 2018 \\
\hline АСЕH & 66.29 & 65.36 & 55.54 & 54.02 & 63.56 & 72.29 & 67.78 & 72.48 & 70.93 & 79.97 \\
\hline SUMATERAUTAPA & 60.20 & 63.45 & 66.15 & 58.51 & 58.80 & 68.02 & 69.01 & 67.37 & 68.08 & 64.33 \\
\hline SUMATERAB EARAT & 60.29 & 63.04 & 65.02 & 60.82 & 54.11 & 63.99 & 9.67 .46 & 54.41 & 69.50 & 67.06 \\
\hline RIAU & 75.85 & 71.45 & 70.65 & 67.00 & 68.37 & 68.40 & \begin{tabular}{l|l}
0 & 65.83 \\
\end{tabular} & 71.89 & 73.41 & 77.59 \\
\hline JAMEI & 71.00 & 65.86 & 70.46 & 68.81 & \begin{tabular}{l|l}
164.41 \\
\end{tabular} & 71.15 & \begin{tabular}{|c|c|c|c|}
5 & 70.68 \\
\end{tabular} & 68.89 & 74.12 & 68.71 \\
\hline SUMATERA SELATAN & 72.52 & 73.65 & 67.92 & 73.17 & 67.12 & 74.82 & \begin{tabular}{|lll}
2 & 79.81 \\
\end{tabular} & 80.95 & 74.04 & 77.14 \\
\hline EENGKULU & 64.76 & 70.78 & 71.36 & 61.70 & 59.17 & 71.70 & \begin{tabular}{|c|c|c|}
0 & 73.60 \\
\end{tabular} & 74.23 & 72.73 & 70.71. \\
\hline LAMPUNG & 67.47 & 67.80 & 74.08 & 72.26 & \begin{tabular}{|c|c|}
6 & 63.13 \\
\end{tabular} & 71.62 & $\begin{array}{ll}265.95 \\
\end{array}$ & 61.00 & 72.01 & 68.67 \\
\hline KEP. BANGKABELITUNG & 67.01 & 65.94 & 67.13 & 69.37 & 68.79 & 75.32 & \begin{tabular}{|l|l|}
2 & 72.31 \\
\end{tabular} & 83.00 & 80.11 & 73.43 \\
\hline KEP. RIAUU & 73.61 & 62.89 & 70.78 & 65.61 & \begin{tabular}{l|l}
1 & 66.50 \\
\end{tabular} & 68.39 & \begin{tabular}{ll|}
9 & 70.26 \\
\end{tabular} & 72.84 & 76.33 & 79.19 \\
\hline DKI JAKARTA & 73.91 & 77.44 & 77.81 & 77.72 & 71.18 & 84.70 & \begin{tabular}{|l|l|}
0 & 85.32 \\
\end{tabular} & 70.85 & 84.73 & 85.08 \\
\hline JAWABAARAT & 71.07 & 59.41 & \begin{tabular}{|c|}
66.18 \\
\end{tabular} & 57.05 & 65.18 & 71.52 & \begin{tabular}{ll|}
2.73 .04 \\
\end{tabular} & 66.82 & 68.78 & 65.50 \\
\hline JAWA TENGAH & 66.45 & 63.42 & 65.59 & 63.79 & \begin{tabular}{l|l}
9 & 60.84 \\
\end{tabular} & 77.44 & \begin{tabular}{l|l|}
4 & 69.75 \\
\end{tabular} & 66.71 & 70.85 & 72.17 \\
\hline DIYOGYAKARTA & 67.55 & 74.33 & 71.67 & 72.96 & \begin{tabular}{|l|l|}
6 & 72.36 \\
\end{tabular} & 82.71 & 4. 83.19 & 85.58 & 83.61 & 80.82 \\
\hline JAWA TIMUR & 62.49 & 55.12 & 55.98 & 54.99 & 59.32 & 70.36 & \begin{tabular}{|l|l|}
6 & 76.90 \\
\end{tabular} & 72.24 & 70.92 & 72.86 \\
\hline BANTEN & 67.98 & 60.60 & \begin{tabular}{|c|}
67.37 \\
\end{tabular} & 65.29 & \begin{tabular}{|l|l|}
969.79 \\
9
\end{tabular} & 75.50 & | 68.46 & 7136 & 73.72 & 73.78 \\
\hline BALL & 70.35 & 72.44 & 74.20 & 71.75 & 72.22 & 76.13 & 79.83 & 78.95 - & 78.80 & 82.37 \\
\hline NUSA TENGGARABARAT & 58.12 & 58.13 & 54.49 & \begin{tabular}{|l|l}
57.97 \\
\end{tabular} & 57.22 & 62.62 & 65.08 & 65.41 & 76.04 & 73.63 \\
\hline NUSA TENGGARA TIMUR & 71.64 & 72.05 & 72.34 & 72.67 & 73.29 & 68.81 & 78.47 & 82.49 & 75.51 & 82.32 \\
\hline KALIMANTANBARAT & 72.38 & 69.32 & 74.86 & 65.38 & 67.52 & 80.58 & 76.40 & 75.28 & 79.13 & 76.14 \\
\hline KaLLMANTAN TENGAH & 77.63 & 71.10 & 76.28 & 65.78 & 64.15 & 79.00 & 73.46 & 74.77 & 76.12 & 71.27 \\
\hline KALLMANTAN SELATAN & 66.63 & 70.94 & \begin{tabular}{|c|c|}
66.47 \\
\end{tabular} & 61.13 & 63.71 & \begin{tabular}{l|l}
70.84 \\
\end{tabular} & 74.76 & 73.43 & 76.25 & 79.92 \\
\hline KALIMANTAN TIMUR & 72.31 & 73.04 & \begin{tabular}{|c|c|}
66.37 & \\
\end{tabular} & 71.23 & 68.13 & 77.77 & 8.24 & 73.64 & 72.86 & 7.88 \\
\hline KALIMANTANUTARA & & & & & & & 80.16 & 76.98 & 81.06 & 81.07 \\
\hline SULAWESIUTARA & 70.94 & 65.94 & 71.19 & 76.50 & 73.11 & 83.94 & 79.40 & 76.34 & 75.76 & 7.77 \\
\hline SULAWESI TENGAH & 66.02 & 66.63 & 64.00 & \begin{tabular}{l|l}
64.97 \\
\end{tabular} & 64.50 & 74.36 & 76.67 & 72.20 & 69.79 & 75.29 \\
\hline SULAWESI SELATAN & 61.48 & 56.67 & 65.31 & 68.55 & 65.20 & 75.30 & 67.90 & 68.53 & 70.79 & 70.88 \\
\hline SULAWESI TENGGARA & 64.29 & 54.79 & 57.56 & 57.26 & 52.61 & 70.13 & 69.44 & 71.13 & 68.51 & 74.32 \\
\hline GORONTALD & 73.50 & 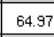 & 62.77 & 59.37 & 67.21 & 73.82 & 76.77 & 77.48 & 73.92 & 72.59 \\
\hline SULAWESIBARAT & 67.99 & \begin{tabular}{|l}
68.82 \\
\end{tabular} & 66.36 & 63.65 & 64.02 & 76.69 & 68.25 & 72.37 & 67.74 & \begin{tabular}{l|l}
4 & 71.46 \\
\end{tabular} \\
\hline MALUKU & 69.07 & 69.51 & 68.38 & 59.68 & 66.23 & 72.72 & 65.90 & 78.20 & \begin{tabular}{|l|l|}
77.45 \\
\end{tabular} & 75.5 \\
\hline MALUKUUTARA & 67.21 & 59.92 & 59.17 & 66.83 & 64.06 & 67.90 & 61.52 & 73.27 & 70.73 & 72.10 \\
\hline PAPUABabat & 63.06 & 67.75 & 61.78 & 65.70 & 60.70 & 65.65 & 59.97 & 60.35 & 62.76 & 58.2. \\
\hline PAPUA & 63.8 & 60.26 & 59.05 & 60.7 & 60.92 & 62.15 & 57.55 & 61.02 & 61.34 & \\
\hline
\end{tabular}

TABLE 2. PRovinCial IDI ASPECT VALUeS IN 2009-2018

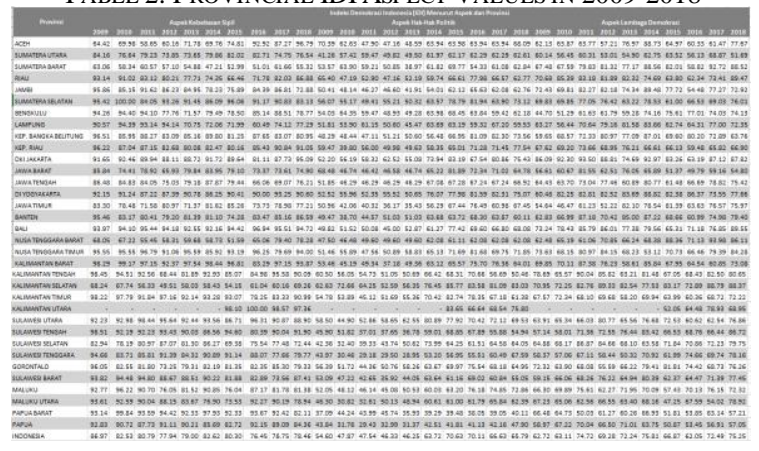

\section{EXPERIMENTAL RESUlts}

The trial results were carried out using a moving average to find the 2019 IDI forecasting value, also to find the MAPE value between provinces and correlation between three main aspect to form IDI. Table 3 displays the results of forecasting IDI in 2019 for each province using moving averages.

TABle 3. ForeCASTING AND MAPE TEST RESUltS FOR EACH PROVINCE AND INDONESIA IN 2019

\begin{tabular}{|c|c|c|c|}
\hline & Name & & \\
\hline 1 & Aceh & & $\begin{array}{l}\text { Nex: } 66.8 \\
\text { RMSEE } 7.2 \\
\text { MSE: } 51.7 \\
\text { MAE: } 6.3 \\
\text { MAPE: } 9.2\end{array}$ \\
\hline 2 & Babel & & $\begin{array}{c}\text { Next: } 72.2 \\
\text { RMSE: } 5.72 \\
\text { MSE: } 32.73 \\
\text { MAE: } 4.25 \\
\text { MAPE: } 5.46\end{array}$ \\
\hline 3 & Bali & $y=$ & $\begin{array}{c}\text { Nex: } 75.7 \\
\text { RMSE } 4.02 \\
\text { MSE: } 16.17 \\
\text { MAE: } 32.32 \\
\text { MAPE: } 4.20\end{array}$ \\
\hline 4 & Banten & & $\begin{array}{l}\text { Nex: } 69.39 \\
\text { RMSE } 4.02 \\
\text { MSE: } 16.17 \\
\text { MAE: } 32.29 \\
\text { MAPE: } 4.51\end{array}$ \\
\hline 5 & Bengkulu & & $\begin{array}{l}\text { Nex: } 69.07 \\
\text { RMSE } 4.87 \\
\text { MSE: } 23.74 \\
\text { MAE: } 4.58 \\
\text { MAPE: } 6.72\end{array}$ \\
\hline 6 & DIY & & $\begin{array}{l}\text { NeX: } 77.48 \\
\text { RMSEE } 6.05 \\
\text { MSEE: } 36.59 \\
\text { MAE: }: .86 \\
\text { MAPE: } 5.87\end{array}$ \\
\hline 7 & $\begin{array}{c}\text { DKI } \\
\text { Jakarta }\end{array}$ & & $\begin{array}{l}\text { Nex: } 78.87 \\
\text { RMSEE:5.63 } \\
\text { MSE: } 51.65 \\
\text { MAE: } 5.09 \\
\text { MAPE: } 6.34\end{array}$ \\
\hline 8 & Gorontalo & & $\begin{array}{c}\text { Next: } 70.24 \\
\text { RMSE: } 5.68 \\
\text { MSE: } 32.25 \\
\text { MAE: } 5.17 \\
\text { MAPE: } 7.28\end{array}$ \\
\hline 9 & Jabar & & $\begin{array}{l}\text { Next: } 66.46 \\
\text { RMSE } 4.15 \\
\text { MSE: } 17.18 \\
\text { MAE: } 31.18 \\
\text { MAPE: } 4.77\end{array}$ \\
\hline 10 & Jambi & & $\begin{array}{l}\text { Next: 69.41 } \\
\text { RMSE: } 2.42 \\
\text { MSE: } 5.88 \\
\text { MAE: } 1.87 \\
\text { MAPE: } 2.67\end{array}$ \\
\hline 11 & Jateng & & $\begin{array}{l}\text { Nex: } 67.70 \\
\text { RMSEE } 4.73 \\
\text { MSEE: 22.33 } \\
\text { MAE: } 2.37 \\
\text { MAPE: } 4.70\end{array}$ \\
\hline 12 & Jatim & & $\begin{array}{l}\text { Next: } 65.12 \\
\text { RMSEE } 8.09 \\
\text { MSEE: } 55.47 \\
\text { MAE: } 6.80 \\
\text { MAPE: } 9.59\end{array}$ \\
\hline 13 & Kalbar & & $\begin{array}{l}\text { Next: } 73.70 \\
\text { RMSE: } 4.74 \\
\text { MSEE: 22.45 } \\
\text { MAE: } 422 \\
\text { MAPE: } 5.63\end{array}$ \\
\hline 14 & Kalsel & & $\begin{array}{l}\text { Next: } 70.40 \\
\text { RMSE: } 5.76 \\
\text { MSEE: } 32.78 \\
\text { MAE: } 5.17 \\
\text { MAPE: } 7.12\end{array}$ \\
\hline 15 & Kalteng & & $\begin{array}{c}\text { Next: } 72.96 \\
\text { RMSE: } 4.43 \\
\text { MSE: } 19.70 \\
\text { MAE: } 3.67 \\
\text { MAPE: } 5.20\end{array}$ \\
\hline
\end{tabular}




\begin{tabular}{|c|c|c|c|}
\hline 16 & Kaltim & $\because=-\Lambda$ & $\begin{array}{c}\text { Next: } 73.05 \\
\text { RMSE: } 4.08 \\
\text { MSE: } 16.64 \\
\text { MAE: } 2.88 \\
\text { MAPE: } 3.83\end{array}$ \\
\hline 17 & Kepri & $=$ & $\begin{array}{c}\text { Next: } 70.64 \\
\text { RMSE: } 4.31 \\
\text { MSE: } 18.58 \\
\text { MAE: } 3.41 \\
\text { MAPE: } 4.60\end{array}$ \\
\hline 18 & Lampung & & $\begin{array}{c}\text { Next: } 68.40 \\
\text { RMSE: } 4.04 \\
\text { MSE: } 16.30 \\
\text { MAE: } 3.50 \\
\text { MAPE: } 5.24\end{array}$ \\
\hline 19 & Maluku & $\begin{array}{l}= \\
\cdots \\
\cdots\end{array}$ & $\begin{array}{c}\text { Next: } 70.27 \\
\text { RMSE: } 5.65 \\
\text { MSE: } 31.93 \\
\text { MAE: } 4.63 \\
\text { MAPE: } 6.43\end{array}$ \\
\hline 20 & Malut & $=$ & $\begin{array}{c}\text { Next: } 66.27 \\
\text { RMSE: } 4.6 \\
\text { MSE: } 21.16 \\
\text { MAE: } 4.04 \\
\text { MAPE: } 5.88\end{array}$ \\
\hline 21 & NTB & & $\begin{array}{c}\text { Next: } 62.87 \\
\text { RMSE: } 7.21 \\
\text { MSE: } 51.95 \\
\text { MAE: } 5.55 \\
\text { MAPE: } 8.03\end{array}$ \\
\hline 22 & $\overline{\mathrm{NTT}}$ & & $\begin{array}{c}\text { Next: } 74.96 \\
\text { RMSE: } 4.63 \\
\text { MSE: } 21.48 \\
\text { MAE: } 3.46 \\
\text { MAPE: } 4.38\end{array}$ \\
\hline 23 & Papua & & $\begin{array}{c}\text { Next: } 60.9 \\
\text { RMSE: } 1.44 \\
\text { MSE: } 2.08 \\
\text { MAE: } 1.07 \\
\text { MAPE: } 1.78\end{array}$ \\
\hline 24 & Kep.Riau & & $\begin{array}{c}\text { Next: } 70.64 \\
\text { RMSE: } 4.31 \\
\text { MSE: } 18.58 \\
\text { MAE: } 3.41 \\
\text { MAPE: } 4.60\end{array}$ \\
\hline 25 & Sulbar & & $\begin{array}{c}\text { Next: } 68.73 \\
\text { RMSE: } 3.80 \\
\text { MSE: } 14.44 \\
\text { MAE: } 2.86 \\
\text { MAPE: } 4.03\end{array}$ \\
\hline 26 & Sulsel & & $\begin{array}{c}\text { Next: } 67.06 \\
\text { RMSE: } 4.89 \\
\text { MSE: } 23.87 \\
\text { MAE: } 4.23 \\
\text { MAPE: } 6.02\end{array}$ \\
\hline 27 & Sulteng & & $\begin{array}{c}\text { Next: } 69.44 \\
\text { RMSE: } 4.76 \\
\text { MSE: } 22.63 \\
\text { MAE: } 3.65 \\
\text { MAPE: } 4.95\end{array}$ \\
\hline 28 & Sultra & & $\begin{array}{c}\text { Next: } 64.00 \\
\text { RMSE: } 7.35 \\
\text { MSE: } 54.00 \\
\text { MAE: } 6.43 \\
\text { MAPE: } 9.46\end{array}$ \\
\hline 29 & Sulut & & $\begin{array}{c}\text { Next: } 75.09 \\
\text { RMSE: } 4.70 \\
\text { MSE: } 22.12 \\
\text { MAE: } 3.67 \\
\text { MAPE: } 4.65\end{array}$ \\
\hline 30 & Sumbar & & $\begin{array}{c}\text { Next: } 62.57 \\
\text { RMSE: } 5.09 \\
\text { MSE: } 25.89 \\
\text { MAE: } 4.63 \\
\text { MAPE: } 7.50\end{array}$ \\
\hline
\end{tabular}

\begin{tabular}{|c|c|c|c|}
\hline 31 & Sumsel & 7 & $\begin{array}{l}\text { Next: } 74.11 \\
\text { RMSE: } 4.33 \\
\text { MSE: } 18.76 \\
\text { MAE: } 3.68 \\
\text { MAPE: } 4.87\end{array}$ \\
\hline 32 & Sumut & & $\begin{array}{l}\text { Next: } 64.39 \\
\text { RMSE: } 3.78 \\
\text { MSE: } 14.30 \\
\text { MAE: } 3.41 \\
\text { MAPE: } 5.21\end{array}$ \\
\hline 33 & Riau & 1 & $\begin{array}{c}\text { Next: } 71.04 \\
\text { RMSE: } 3.56 \\
\text { MSE: } 12.70 \\
\text { MAE: } 3.23 \\
\text { MAPE: } 4.55\end{array}$ \\
\hline 34 & Kalut & V. & $\begin{array}{l}\text { Next: } 79.81 \\
\text { RMSE: } 1.11 \\
\text { MSE: } 1.24 \\
\text { MAE: } 0.68 \\
\text { MAPE: } 0.86\end{array}$ \\
\hline 35 & PapuaBar & & $\begin{array}{c}\text { Next: } 62.60 \\
\text { RMSE: } 2.69 \\
\text { MSE: } 7.25 \\
\text { MAE: } 2.39 \\
\text { MAPE: } 3.94\end{array}$ \\
\hline 36 & Indonesia & & $\begin{array}{c}\text { Next: } 68.28 \\
\text { RMSE: } 4.10 \\
\text { MSE: } 16.79 \\
\text { MAE: } 3.4 \\
\text { MAPE: } 4.78\end{array}$ \\
\hline
\end{tabular}

Table 3 shows the results of forecasting tests and MAPE calculations using Moving Averages from 35 Provinces in Indonesia. The results of the trial stated that all provinces were in the category of "medium", but there were provinces that approached the "bad" category including the Provinces of Papua, West Sumatra, and West Papua with IDI forecasting of 60.9; 62.57; and 62.60. Provinces and approaching and potentially getting the "good" category are DI Yogyakarta and DKI Jakarta Provinces with IDI forecasting values of 77.48 and 78.87. Whereas IDI Indonesia for 2019 is predicted to be 68.28 with a MAPE value of $4.78 \%$

Based on experiment to find the Pearson correlation coefficient on three aspects, the results obtained as in Table 4 and Table 5 below. From the calculation of the Pearson correlation coefficient, it can be seen that the aspect of civil liberties has no correlation with the aspects of political rights or aspects of democratic institutions with an average Pearson value of -0.05 and -0.19 . While the aspect of political rights has a relationship with aspects of democratic institutions with an average value of Pearson of 0.48

Table 4. Calculation Results ofArithmetic, Geometric, And HARMONIC MEANS ON THE ASPEC OF IDI 2009-2018

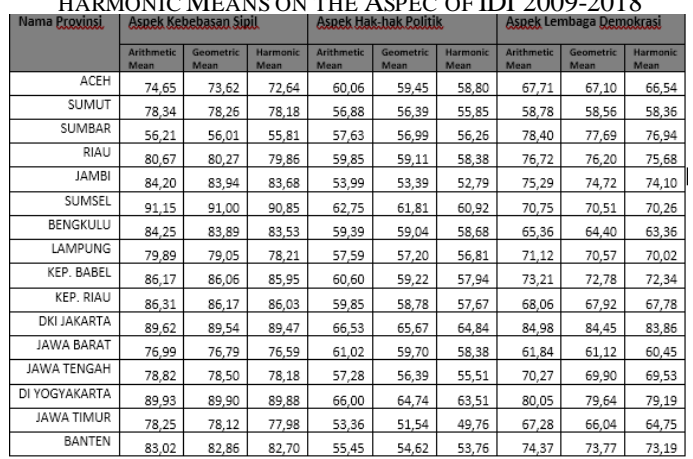




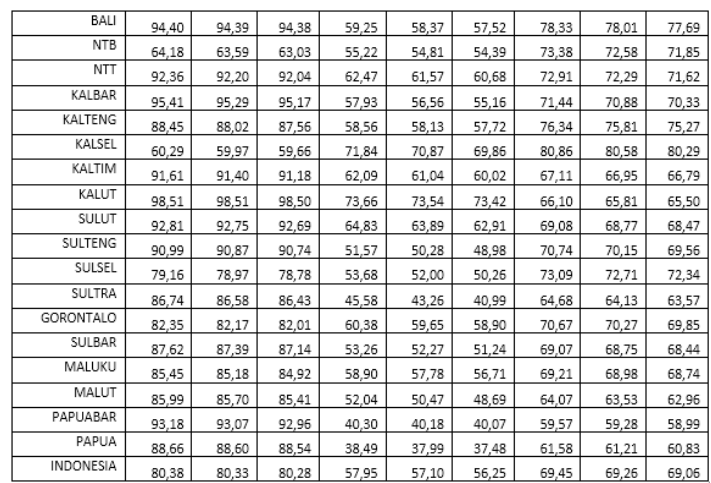

TABle 5. RESUltS OF THE PEARSON CORRELATION EFFICIENT CALCUlation ON 3 ASPECTS FORMING IDI

\begin{tabular}{|c|c|c|}
\hline \multirow{3}{*}{$\begin{array}{l}\text { Keterkaitan Aspek } \\
\text { hak-hak sipil dengan } \\
\text { Aspek hak-hak politik }\end{array}$} & \begin{tabular}{|l|} 
pearson \\
arithmetic mean
\end{tabular} & $-0,04$ \\
\hline & $\begin{array}{l}\text { pearson } \\
\text { geometric mean }\end{array}$ & $-0,05$ \\
\hline & $\begin{array}{l}\text { pearson } \\
\text { harmonic mean }\end{array}$ & $-0,049$ \\
\hline \multirow{3}{*}{$\begin{array}{l}\text { Keterkaitan Aspek } \\
\text { hak-hak sipil dengan } \\
\text { Aspek lembaga } \\
\text { demokrasi }\end{array}$} & $\begin{array}{l}\text { pearson } \\
\text { arithmetic mean }\end{array}$ & $-0,20$ \\
\hline & $\begin{array}{l}\text { pearson } \\
\text { geometric mean }\end{array}$ & $-0,19$ \\
\hline & $\begin{array}{l}\text { pearson } \\
\text { harmonic mean }\end{array}$ & -0, \\
\hline \multirow{3}{*}{$\begin{array}{l}\text { Keterkaitan Aspek } \\
\text { hak-hak politik } \\
\text { dengan Aspek }\end{array}$} & $\begin{array}{l}\text { pearson } \\
\text { arithmetic mean }\end{array}$ & 0,48 \\
\hline & $\begin{array}{l}\text { pearson } \\
\text { geometric mean }\end{array}$ & 0,484 \\
\hline & $\begin{array}{l}\text { pearson } \\
\text { harmonic mean }\end{array}$ & 0,483 \\
\hline
\end{tabular}

\section{CONCLUSION}

Based on the results of experiments conducted conclusions can be specified, namely: IDI Forecasting Results using the 2019 moving average method resulted in all provinces included in the category of "medium" and the predicted value for IDI 2019 reached 68.28 with a MAPE value of $4.78 \%$. The experimental results to find out the choreography between the three aspects of forming the IDI using the Pearson correlation coefficient results in the aspect of civil liberties having no correlation with aspects of political rights or aspects of democratic institutions with Pearson values of -0.05 and -0.19 . Whereas aspects of political rights correlate with democratic institutions with Pearson's value of 0.48 .

\section{REFERENCES}

1] Nurlifa Alfian, Kusumadewi Sri. 2017. Sistem Peramalan Jumlah Penjualan Menggunak an Metode Moving average pada Rumah Jilbab Zaky. Jurnal Inovtek Polbeng. Vol-2. No. 1.

[2] C. Narendra Babu, B. Eswara Reddy. 2014. A moving-average filterbased hybrid ARIMA-ANN model for forecasting time series data. Applied Soft Computing. Elsevier. Vol-23. Pages 27-38.

[3] Dana Indra Sensuse, C. Elin, Wibowo. Wahyu Catur. 2015. Identifying Knowledge Management Process of Indonesian Government Human Capital Management Using Analytical Hierarcy Process and Pearson Correlation Analysis, Procedia Computer Science. Elsevier. Vol-72. Pages 233-243.

[4] Iwan, Eneng Iviq H.R, Yulianto A 2018. Analisa Peramalan Permintaan Mobil Mitsubishi Xpander dengan tiga Metode Forecasting. Cakrawal a. Jurnal Humaniora Bina Sarana Informatika. Vol-18 No. 2.

[5] [5Shigeru Furuichi. (2014). Operator inequalities among arithmetic mean, geometric mean, and harmonic mean. Jurnal of Mathematical Inequalities. Vol. 8, No. 3. Pp. 669-672. 